\title{
Pengaruh Persentase Serat Eceng Gondok terhadap Sifat Fisik dan Mekanik Papan Beton Busa
}

\author{
Defta Eka Sari*, Alimin Mahyudin \\ Jurusan Fisika FMIPA Universitas Andalas Kampus Unand, Limau Manis, Padang, 25163 \\ *ekasaridefta@yahoo.com
}

\begin{abstract}
ABSTRAK
Telah dilakukan penelitian tentang pengaruh persentase serat eceng gondok terhadap sifat fisik dan mekanik papan beton busa. Persentase serat eceng gondok yang digunakan yaitu $0 \% ; 2,5 \% ; 5 \% ; 7,5 \%$ dan $10 \%$ terhadap volume papan dengan metode penyusunan serat secara two dimensional reinforcement (dua arah). Persentase foam agent yang digunakan tetap yaitu 0,06 \% terhadap volume papan. Pengujian yang dilakukan yaitu sifat fisik berupa daya serap air, densitas dan porositas sedangkan sifat mekanik berupa kuat tekan dan kuat lentur dengan perawatan papan selama 28 hari. Alat uji kuat tekan dan kuat lentur menggunakan Universal Testing Machine (UTM). Dari hasil penelitian daya serap air rerata terendah dicapai papan beton busa tanpa serat sebesar 11,10\%, densitas rerata terendah papan beton busa dengan persentase serat $10 \%$ sebesar $1,67 \mathrm{~g} / \mathrm{cm}^{3}$, porositas rerata terendah pada papan beton busa tanpa serat sebesar $18,93 \%$, kuat tekan rerata tertinggi pada papan beton busa tanpa serat sebesar $98,4 \mathrm{~kg} / \mathrm{cm}^{2}$ dan kuat lentur rerata tertinggi pada papan beton busa dengan persentase serat 2,5\% sebesar 58,50 $\mathrm{kg} / \mathrm{cm}^{2}$.

Kata kunci: daya serap air, densitas, foam agent, kuat lentur, kuat tekan, papan beton busa, porositas.
\end{abstract}

\begin{abstract}
The research about the influence of percentage of water hyacinth fiber on the physical and mechanical properties of the foamed concrete board has been conducted. The percentage of hyacinth fiber used is 0 $\% ; 2.5 \% ; 5 \% ; 7.5 \%$ and $10 \%$ to the board volume by two dimensional reinforcement (two way direction) method. The percentage of fixed foam agent used is $0.06 \%$ to the board volume. The tests performed are physical properties of water absorption, density and porosity while the mechanical properties are compressive strength and flexural strength using universal testing machine (UTM). The result, show that the lowest average water absorption reached for foamed concrete board without fiber, that is $11.10 \%$, the lowest average density $\left(1.67 \mathrm{~g} / \mathrm{cm}^{3}\right)$ is at the foamed concrete board with $10 \%$ fiber percentage, the lowest average porosity $(18.93 \%)$ is at the foamed concrete board without fiber, the highest average compressive strength $\left(98.4 \mathrm{~kg} / \mathrm{cm}^{2}\right)$ is at the foamed concrete board without fiber and the highest average flexural strength $\left(58.50 \mathrm{~kg} / \mathrm{cm}^{2}\right)$ of the foamed concrete board with $2.5 \%$ fiber percentage.
\end{abstract}

Keywords: water absorption, density, foam agent, flexural strength, compressive strength, foamed concrete board, porosity.

\section{PENDAHULUAN}

Material komposit adalah material yang tersusun dari dua campuran atau lebih dengan sifat kimia dan fisika berbeda, dan menghasilkan sebuah material baru yang memiliki sifat berbeda dari material-material penyusunnya. Material komposit tersusun dari material yang mengkombinasikan fasa matriks dengan campuran filler yang berfungsi sebagai fasa penguat (Smallman dan Bishop, 2000). Filler yang digunakan dalam penelitian ini serat eceng gondok, hal ini dikarenakan tanaman eceng gondok memiliki kualitas serat yang kuat, kandungan serat cukup tinggi sehingga mampu mempercepat proses pengeringan air dalam adukan beton dan bahan baku yang melimpah serta tidak beracun (Gunawan dkk, 2017).

Matriks yang digunakan dalam penelitian ini terdiri dari campuran semen, agregat halus (pasir) dan air. Hal yang mempengaruhi ikatan antara serat dan matriks adalah void, yaitu adanya celah pada serat atau bentuk serat yang kurang sempurna yang dapat menyebabkan matriks tidak akan mampu mengisi ruang kosong pada cetakan. Bila komposit tersebut menerima beban, maka daerah tegangan akan berpindah ke daerah void sehingga akan mengurangi kekuatan komposit tersebut. Dengan adanya partikel berupa serat, maka daerah kekosongan pada matriks akan terisi oleh partikel, sehingga deformasi yang terjadi dapat diminimalisir oleh partikel. Persentase serat eceng gondok yang digunakan dalam penelitian ini yaitu $0 \% ; 2,5 \% ; 5 \% ; 7,5 \%$ dan $10 \%$ terhadap volume cetakan. 
Penelitian tentang pengaruh persentase massa gipsum dan serat terhadap kuat tekan dan kuat lentur papan semen-gipsum berserat eceng gondok telah dilakukan Qorina (2016) diperoleh nilai kuat tekan paling tinggi $14,52 \mathrm{~kg} / \mathrm{cm}^{2}$ dan nilai kuat lentur paling tinggi 1,265 $\mathrm{kg} / \mathrm{cm}^{2}$ pada persentase massa serat tetap 2,5\% dan massa gipsum $30 \%$. Nilai kuat tekan tertinggi sebesar $24,99 \mathrm{~kg} / \mathrm{cm}^{2}$ pada persentase massa serat $7,5 \%$ dan massa gipsum tetap $30 \%$ sedangkan nilai lentur tertinggi sebesar $1,575 \mathrm{~kg} / \mathrm{cm}^{2}$ pada persentase massa serat $5 \%$ dan massa gipsum tetap $30 \%$.

Penambahan foam agent dalam penelitian ini bertujuan untuk membuat papan beton yang dihasilkan menjadi ringan. Foam agent adalah suatu larutan pekat dari bahan surfaktan, dimana apabila hendak digunakan harus dilarutkan dengan air. Surfaktan adalah zat yang cenderung terkonsentrasi pada antar muka dan mengaktifkan antar muka tersebut. Dengan membuat gelembung-gelembung udara dalam adukan semen, sehingga akan timbul banyak pori-pori udara di dalam betonnya (Husin dan Setiadji, 2008). Dalam pemakaiannya perbandingan foam agent dan air adalah 1:40. Ukuran gelembung yang dihasilkan oleh foam agent adalah 0,25 - 0,5 mm dan menghasilkan busa yang lebih keras (Putranto dkk, 2017).

Penelitian ini menggunakan persentase foam agent tetap untuk setiap sampel yaitu 0,06 $\%$ terhadap volume cetakan. Persentase ini didasari dari penelitian yang dilakukan oleh Trinugroho dan Murtono (2015) tentang pemanfaatan foam agent dan material lokal dalam pembuatan bata ringan dihasilkan kuat tekan tertinggi pada beton dengan kandungan foam agent $0,6 \mathrm{~L} / \mathrm{m}^{3}$ menggunakan pasir kuarsa sebesar 4,02 MPa dan kuat lentur balok beton dengan kandungan foam agent $0,6 \mathrm{~L} / \mathrm{m}^{3}$ menggunakan pasir woro sebesar $0,738 \mathrm{MPa}$.

Dalam pembuatan komposit tata letak dan arah serat dalam matriks yang akan menentukan kekuatan mekanik komposit dimana letak dan arah dapat mempengaruhi kinerja komposit tersebut. Menurut tata letak dan arah serat diklasifikasikan menjadi 3 bagian yaitu: one dimensional reinforcement, two dimensional reinforcement dan three dimensional reinforcement (Schwartz, 1984). Orientasi serat two dimensional reinforcement dikenal juga dengan penyusunan serat secara planar. Pada penelitian ini orientasi seratnya secara dua arah. Penelitian ini bertujuan untuk mengetahui persentase optimum serat eceng gondok pada papan beton yang dicampur foam agent. Hasil penelitian ini dibandingkan dengan Standar Nasional Indonesia (SNI) 03-2105-2006 dan 03-3449-2002.

\section{METODE}

Penelitian ini dilaksanakan pada bulan Juli sampai Desember 2017. Pembuatan sampel dan pengujian sifat fisik berupa (daya serap air, densitas, dan porositas) papan beton busa dilakukan di Laboratorium Fisika Material Jurusan Fisika Universitas Andalas. Pengujian sifat mekanik papan beton busa berupa kuat tekan dan kuat lentur dilakukan di Laboratorium Mekanik Politeknik Negeri Padang. Peralatan yang digunakan sebagai berikut: neraca digital, Universal Testing Machine (UTM), ayakan ukuran 50 mesh, gelas ukur, sendok semen, mixer, ember, oven, cawan porselin, kikir, cetakan ukuran $5 \mathrm{~cm} \times 5 \mathrm{~cm} \times 1 \mathrm{~cm}$ dan cetakan ukuran 20 $\mathrm{cm} \times 5 \mathrm{~cm} \times 1 \mathrm{~cm}$. Bahan penelitian yang digunakan seperti semen Portland dari PT. Semen Padang, pasir gunung, air, aquades, $\mathrm{NaOH}$ dan serat eceng gondok.

Batang eceng gondok dikeringkan di bawah sinar matahari selama \pm 7 hari (sampai benar-benar kering). Batang eceng gondok dibelah dan potong tipis-tipis sehingga memiliki diameter 0,1 - 0,15 mm. Serat direndam dengan larutan $\mathrm{NaOH} 5 \%$ selama 2 jam, lalu dicuci bersih menggunakan aquades, dikeringkan dengan oven pada suhu $\pm 40^{\circ} \mathrm{C}$ selama 2 jam dan dipotong dengan panjang $1 \mathrm{~cm}$. Pasir gunung diayak menggunakan ukuran 50 mesh. Pasta beton yang dibuat dengan rasio semen:pasir yaitu 1:2 dan faktor air semen (FAS) 0,4. Proses pembentukan busa dengan rasio foam agent:air yaitu 1:40 lalu di mixer. Pasta yang udah dicampurkan dengan foam agent dituangkan kedalam cetakan, diisi penyusunan serat secara acak sesuai dengan masing-masing persentase serat dan dilapisi kembali dengan pasta pada bagian atasnya. Sampel dibuat 3 buah untuk masing-masing variasi persentase serat.

Pengujian sampel uji dilakukan setelah berumur 28 hari dengan pengujian sifat fisik yaitu uji daya serap air, densitas, dan porositas sedangkan pengujian sifat mekanik yaitu uji kuat tekan dan kuat lentur. Nilai sifat fisik yang diperoleh dalam penelitian ini dibandingkan dengan 
standar mutu SNI 03-2105-2006 dan sifat mekanik dengan standar mutu SNI 03-3449-2002. Rumus yang digunakan untuk pengolahan data dalam penelitian sebagai berikut:

$$
\text { Daya Serap Air }=\frac{m_{b}-m_{k}}{m_{k}} \times 100 \%
$$

Daya serap air dinyatakan dalam satuan $\%, m_{k}$ merupakan massa kering sampel yang diukur dalam saturan gram sedangkan $m_{b}$ merupakan massa basah yang diukur setelah direndam dalam air selama 24 jam dalam satuan gram.

$$
\rho=\frac{m_{k}}{V}
$$

$\rho$ merupakan lambang densitas untuk menentukan ukuran kepadatan dari sampel uji. $m_{k}$ merupakan massa kering sampel sebelum direndam dalam air (dalam satuan gram). $V$ merupakan volume sampel uji dalam satuan $\mathrm{cm}^{3}$.

$$
\text { Porositas }=\frac{m_{b}-m_{k}}{V} \times \frac{1}{\rho_{a}} \times 100 \%
$$

Porositas merupakan pengujian yang dilakukan untuk mengetahui besarnya pori-pori pada sampel uji dalam satuan \%. $m_{k}$ merupakan massa kering sampel sebelum direndam dalam air (dalam satuan gram). $m_{b}$ merupakan massa sampel setelah direndan dengan air dalam satuan gram. $V$ merupakan volume uji dengan satuan $\mathrm{cm}^{3} . \rho_{a}$ merupakan massa jenis air dengan nilai 1 $\mathrm{g} / \mathrm{cm}^{3}$.

$$
f_{c}=\frac{P}{A}
$$

$f_{c}$ merupakan kuat tekan yang dihasilkan sampel dengan satuan $\mathrm{kg} / \mathrm{cm}^{2}, P$ merupakan beban maksimum dalam satuan $\mathrm{kg}$ yang diperoleh dari mesin uji UTM dan $A$ merupakan luas permukaan sampel yang diuji dalam satuan $\mathrm{cm}^{2}$.

$$
f_{r}=\frac{3 m_{p} S}{2 L T^{2}}
$$

$f_{r}$ merupakan kuat lentur sampel uji dengan satuan $\mathrm{kg} / \mathrm{cm}^{2}, m_{p}$ merupakan beban maksimum yang dihasilkan oleh mesin UTM dalam satuan $\mathrm{kg}, S$ merupakan jarak tumpuan sampel terhadap beban (dalam penelitian ini jarak tumpuannya $15 \mathrm{~cm}$ ), $L$ merupakan lebar sampel uji (dalam penelitian ini $5 \mathrm{~cm}$ ) dan $T$ merupakan tebal sampel uji (dalam penelitian ini $1 \mathrm{~cm}$ ).

\section{HASIL DAN DISKUSI}

\subsection{Uji Daya Serap Air}

Daya serap air menunjukkan kemampuan papan beton busa menyerap air. Gambar 1 merupakan hasil pengujian daya serap air untuk papan beton busa dengan variasi serat eceng gondok $0 \% ; 2,5 \% ; 5 \% ; 7,5 \%$; dan $10 \%$ telah memenuhi standar mutu SNI 03-2105-2006 dengan nilai daya serap air kurang dari $14 \%$. Pada papan beton busa tanpa serat nilai daya serap airnya paling rendah yaitu $11,1 \%$. Nilai daya serap air semakin meningkat seiring bertambahnya persentase serat eceng gondok terhadap komposisi papan beton busa dengan nilai daya serap air rata-rata secara berturut-turut yaitu $11.35 \% ; 11,46 \% ; 12,05 \%$ dan $12,68 \%$. Kenaikan nilai daya serap air papan beton busa disebabkan serat eceng gondok memiliki kemampuan dalam menyerap air. 


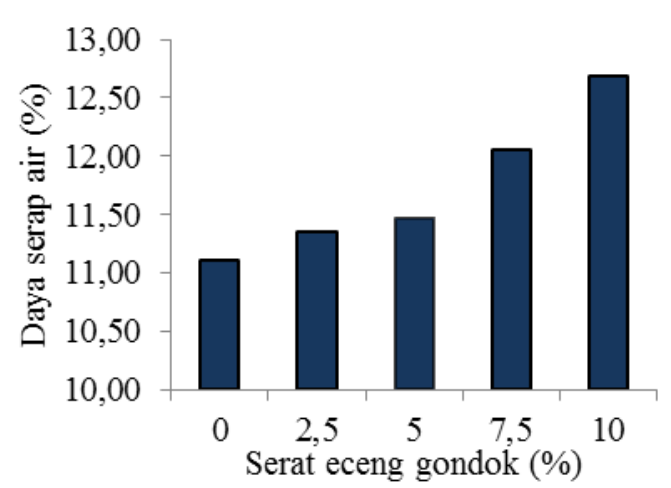

Gambar 1 Pengaruh persentase serat eceng gondok terhadap daya serap air papan beton busa.

\subsection{Uji Densitas}

Gambar 2 menunjukkan nilai densitas rata-rata papan beton busa tanpa serat memiliki nilai paling tinggi yaitu $1,71 \mathrm{~g} / \mathrm{cm}^{3}$. Semakin bertambahnya persentase serat eceng gondok pada papan beton busa maka nilai densitas rata-ratanya semakin menurun dengan nilai secara berturut-turut $1,7 \mathrm{~g} / \mathrm{cm}^{3}, 1,69 \mathrm{~g} / \mathrm{cm}^{3}, 1,68 \mathrm{~g} / \mathrm{cm}^{3}$ dan $1,67 \mathrm{~g} / \mathrm{cm}^{3}$. Menurunnya nilai densitas papan beton busa dipengaruhi oleh massa sampel yang lebih ringan akibat bertambahnya persentase serat eceng gondok dalam papan sehingga massa campuran beton semakin berkurang. Nilai densitas papan beton busa berserat eceng gondok yang dihasilkan ini belum memenuhi standar mutu SNI 03-2105-2006 dengan rentang nilai densitas 0,40-0,90 g/ $\mathrm{cm}^{3}$. Ada hubungan yang berlawanan antara daya serap air dengan densitas papan beton busa, semakin tinggi daya serap air papan beton busa maka semakin rendah densitasnya.

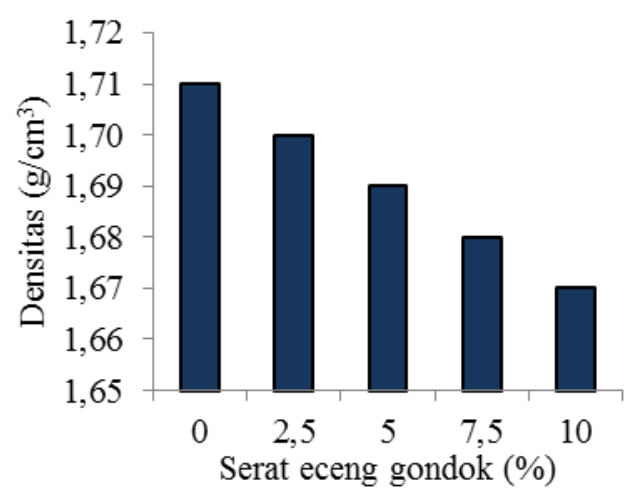

Gambar 2 Pengaruh persentase serat eceng gondok terhadap densitas papan beton busa.

\subsection{Uji Porositas}

Gambar 3 menunjukkan kenaikan nilai porositas rata-rata seiring bertambahnya persentase serat eceng gondok dengan nilai porositas secara berturut-turut 19,29\%; 19,39\%; $20,27 \%$ dan $21,05 \%$. Ini berarti persentase serat eceng gondok terhadap papan beton busa begitu besar pengaruhnya sehingga semakin besar persentase serat yang digunakan maka nilai porositas papan yang dihasilkan juga semakin besar. Penambahan serat eceng gondok dalam papan beton busa menambah besarnya pori-pori yang terdapat dalam papan beton busa sehingga papan mudah menyerap air. Semakin kecil nilai densitas maka daya serap air semakin tinggi. Nilai densitas kecil disebabkan pada saat penyusunan serat eceng gondok ke dalam cetakan papan lebih banyak terdapat rongga udara, maka porositasnya akan lebih besar. 


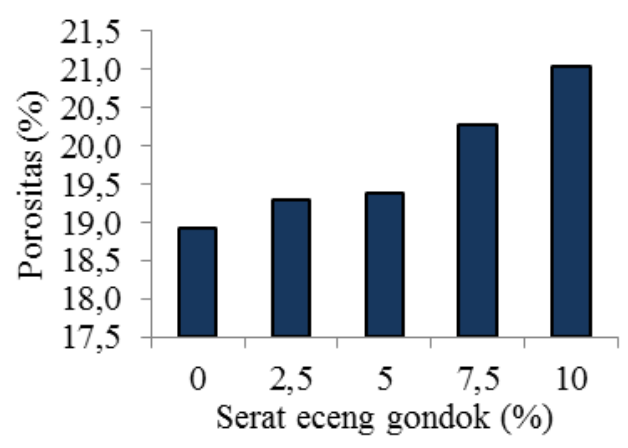

Gambar 3 Pengaruh persentase serat eceng gondok terhadap porositas papan beton busa.

\subsection{Uji Kuat Tekan}

Pengaruh penambahan serat eceng gondok terhadap nilai kuat tekan rata-rata papan beton busa dapat dilihat pada Gambar 4. Kuat tekan papan beton busa terendah terdapat pada persentase $2,5 \%$, sedangkan kuat tekan yang tertinggi didapatkan pada papan beton busa tanpa komposisi serat eceng gondok. Dalam persentase $2,5 \% ; 5 \%$; dan 7,5\% serat eceng gondok didapatkan nilai kuat tekan papan beton busa meningkat seiring bertambahnya serat dan mengalami penurunan nilai kuat tekan pada persentase serat $10 \%$. Artinya pada persentase serat tertentu dapat meningkatkan nilai kuat tekan papan beton busa karena mampu mempengaruhi ikatan matriks dalam papan menjadi sangat kuat. Berdasarkan data yang diperoleh kuat tekan rata-rata papan beton busa dengan variasi serat eceng gondok sudah memenuhi nilai kuat tekan standar mutu SNI 03-3449-2002 untuk struktural ringan yaitu dengan rentang nilai kuat tekan $68,9-172,4 \mathrm{~kg} / \mathrm{cm}^{2}$.

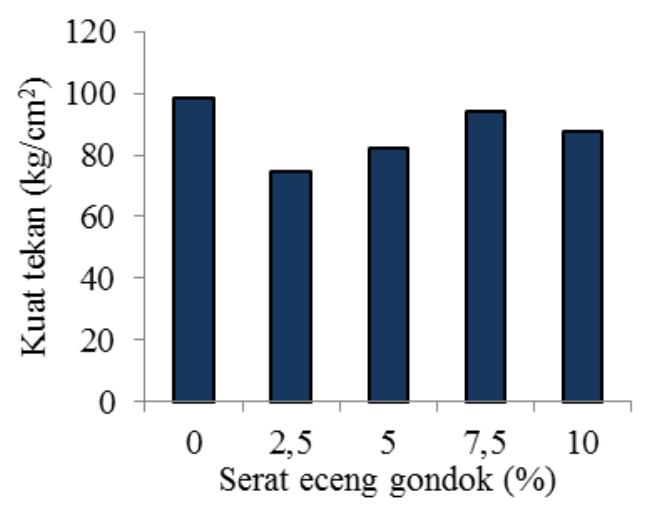

Gambar 4 Pengaruh persentase serat eceng gondok terhadap kuat tekan papan beton busa.

\subsection{Uji Kuat Lentur}

Pengaruh persentase serat eceng gondok terhadap kuat lentur papan beton busa lebih jelasnya dapat dilihat pada Gambar 5. Nilai kuat lentur rata-rata terendah diperoleh papan beton busa tanpa serat eceng gondok yaitu $39 \mathrm{~kg} / \mathrm{cm}^{2}$. Nilai kuat lentur papan beton busa berserat eceng gondok tertinggi diperoleh dengan persentase serat $2,5 \%$ yaitu $58,50 \mathrm{~kg} / \mathrm{cm}^{2}$. Pada persentase $2,5 \%$ serat eceng gondok terhadap volume papan beton busa dapat dikatakan bahwa serat eceng gondok bersifat memperkuat ikatan antara serat terhadap matriks. Penambahan serat eceng gondok yang berlebihan akan membuat nilai kuat lentur papan beton busa menurun, seperti yang terlihat pada persentase $5 \% ; 7,5 \%$ dan $10 \%$ dengan nilai kuat lentur berturut turut $48 \mathrm{~kg} / \mathrm{cm}^{2}, 42 \mathrm{~kg} / \mathrm{cm}^{2}$ dan $45 \mathrm{~kg} / \mathrm{cm}^{2}$. Nilai kuat lentur yang didapat lebih kecil dari persentase $2,5 \%$. Hal ini disebabkan oleh massa beton berkurang, serat eceng gondok pendek sehingga tidak dapat memperkuat ikatan antara serat dan matriks. Sifat serat eceng gondok yang 
mengembang membuat papan memiliki pori-pori kecil yang membuat papan menjadi lebih rapuh atau mudah patah sehingga memiliki nilai kuat lentur yang semakin rendah.

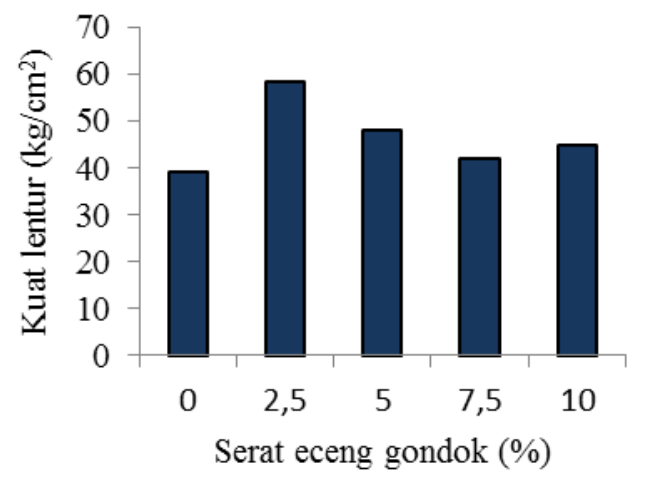

Gambar 5 Pengaruh persentase serat eceng gondok terhadap kuat lentur papan beton busa.

\section{KESIMPULAN}

Dari penelitian yang telah dilakukan dapat disimpulkan bahwa persentase serat eceng gondok yang dapat digunakan sebagai bahan baku dalam pembuatan papan beton busa dengan persentase serat 2,5\% terhadap volume papan. Parameter ini ditentukan karena pada persentase serat 2,5\% dihasilkan nilai kuat lentur papan beton busa yang paling tinggi dan nilai kuat tekan pada persentase ini juga memenuhi nilai standar mutu SNI 03-3449-2002.

\section{DAFTAR PUSTAKA}

Badan Standardisasi Nasional (BSN), 2006, Papan Partikel, Indonesia, SNI 03-2105-2006.

Badan Standardisasi Nasional (BSN), 2002, Tata Cara Rencana Pembuatan Campuran Beton Ringan dengan Agregat Ringan, Indonesia, SNI 03-3449-2002.

Gunawan, P., Wibowo dan Suryawan, N., 2014, Pengaruh Penambahan Serat Polypropilene pada Beton Ringan dengan Teknologi Foam terhadap Kuat Tekan, Kuat Tarik Belah dan Modulus Elastisitas, e-Jurnal Matriks Teknik Sipil, Surakarta, Vol. 2, No. 2.

Husin, A. dan Setiadji, R.,2008, "Pengaruh Penambahan Foam agent terhadap Kualitas Bata Ringan", Pusat Litbang Permukiman, Bandung.

Putranto, S., Chundakus, H. dan Anis, R., 2017, Pengaruh Fly Ash sebagai Bahan Tambah Beton Ringan Foam terhadap Berat Jenis, Kuat Tekan dan Daya Serap Air untuk Material Dinding Struktur, JIPTEK, Vol. 10, No. 1.

Qorina, U., 2016, "Pengaruh Persentase Massa Gipsum dan Serat terhadap Kuat Tekan dan Kuat Lentur Papan Semen Gipsum Berserat Eceng Gondok", Skripsi, FMIPA, UNAND, Padang.

Roseno, S., 2008, "Serat Alam Sebagai Penguat Produk Komposit Ramah Lingkungan", Pusat Teknologi Material, BPPT, Jakarta.

Schwartz, M.M., 1984, "Composite Material Handbook", Mc. Graw Hill, Book Company.

Smallman, R.E. dan Bishop R.J., 2000, "Metalurgi Fisik Modern dan Rekayasa Material", Edisi Keenam, Erlangga, Jakarta.

Trinugroho, S. dan Amir, M., 2015, Pemanfaatan Foam agent dan Material Lokal dalam Pembuatan Bata Ringan, Universitas Muhammadiyah Surakarta.

Vlack, L.H.V., 1983, "Ilmu dan Teknologi Bahan (Ilmu Logam dan Bukan Logam)", Edisi Keempat, Erlangga, Jakarta. 